\title{
Tanggung Jawab Notaris Akibat Batalnya Akta Perjanjian Pengikatan Jual Beli Tanah Karena Cacat Hukum
}

\author{
Anak Agung Deby Wulandari ${ }^{1}$ \\ ${ }^{1}$ Program Studi Magister (S2) Kenotariatan Fakultas Hukum Universitas Udayana, Bali- \\ Indonesia, E-mail: agungdebywulandari@gmail.com
}

\begin{tabular}{l}
\hline Info Artikel \\
Keywords : \\
Agreement, Sale and Purchase, \\
Legal Protection, Cancellation. \\
\\
\\
DOI : \\
10.24843/ AC.2018.v03.i03.p0 \\
Corresponding Author: \\
Anak Agung Deby Wulandari, \\
Email: \\
agungdebywulandari@gmail.co \\
m \\
Kata kunci: \\
Perjanjian, Jual Beli, \\
Pembatalan. \\
\end{tabular}

\begin{abstract}
Law of the Republic of Indonesia Number 2 of 2014 concerning Amendments to Law Number 30 Year 2004 concerning Notary Position (UUJN) gives authority to notaries to make an agreement. According to that regulation, of course the notary has an important role in the making of the land sale and purchase agreement. A land sale and purchase agreement must meet the subjective requirements and objective requirements as contained in Article 1320 of the Civil Code (KUHPerdata). The problems that occur are: (1) How is the position of the deed of binding agreement on the sale and purchase of land containing legal defects? and (2) How is the notary's responsibility related to the cancellation of the binding contract of sale and purchase agreement due to a legal defect in its manufacture? The type of this research is legal research. The results of this research indicate that the position of the deed of binding agreement on sale and purchase of land that contains legal defects is not as a deed that has perfect proof power, so that the law can be canceled or null and void by law. This is related to subjective requirements and objective conditions in the provisions of Article 1320 of the Civil Code. The responsibility of the notary is related to the cancellation of the binding agreement on the sale and purchase of land due to a legal defect in the form of notary public, criminal, administrative, and notary codes of conduct.
\end{abstract}

\begin{tabular}{l} 
Abstrak \\
\hline Undang-Undang Republik Indonesia Nomor 2 Tahun 2014 \\
Tentang Perubahan Atas Undang-Undang Nomor 30 Tahun \\
2004 Tentang Jabatan Notaris (UUJN) memberikan kewenangan \\
kepada notaris untuk membuat suatu perjanjian. Terkait dengan \\
hal tersebut tentunya notaris memiliki peran penting dalam \\
pembuatan Perjanjian Pengikatan Jual Beli (PPJB) tanah. Suatu \\
perjanjian jual beli tanah harus memenuhi syarat subjektif dan \\
syarat objektif sebagaimana terkadung dalam Pasal 1320 Kitab \\
Undang-Undang Hukum Perdata (KUHPerdata). Permasalahan \\
yang terjadi yaitu: (1) Bagaimanakah kedudukan akta perjanjian \\
pengikatan jual beli tanah yang mengandung cacat hukum? dan \\
(2) Bagaimanakah pertanggungjawaban notaris terkait dengan \\
batalnya akta perjanjian pengikatan jual beli tanah diakibatkan \\
adanya cacat hukum dalam pembuatannya?. Penelitian ini \\
beranjak dari penelitian hukum normatif. Hasil penelitian dapat \\
diketahui bahwa kedudukan akta perjanjian pengikatan jual beli \\
tanah yang mengandung cacat hukum yaitu tidak sebagai akta
\end{tabular}


yang memiliki kekuatan pembuktian yang sempurna, sehingga berakibat hukum akta dapat dibatalkan atau batal demi hukum. Hal ini berkaitan dengan syarat subjektif dan syarat objektif dalam ketentuan Pasal 1320 KUHPerdata. Pertanggungjawaban notaris terkait dengan batalnya akta perjanjian pengikatan jual beli tanah diakibatkan adanya cacat hukum dalam pembuatannya yaitu notaris dapat dimintakan pertanggungjawabannya secara perdata, pidana, administrasi, dan terhadap kode etik notaris.

\section{Pendahuluan}

Notaris merupakan suatu profesi yang juga menempati posisi sebagai pejabat umum. Dalam posisinya sebagai profesional di bidang hukum, notaris berperan dalam menciptakan kepastian hukum bagi masyarakat dalam rangka penegakan hukum. Notaris merupakan suatu profesi yang tercipta secara tidak langsung dari hasil interaksi antar masyarakat yang kemudian berkembang dalam memenuhi kebutuhan masyarakat itu sendiri. ${ }^{1}$ Peran notaris sebagai ranah pencegahan (preventif) agar tidak terjadi permasalahan hukum dilakukan dengan menerbitkan akta otentik sebagai alat bukti tertulis dengan kekuatan pembuktian sempurna, yang dapat memberikan kontribusi nyata dalam penyelesaian sengketa apabila terjadi sengeketa di kemudian hari. ${ }^{2}$ Jabatan notaris di Indonesia diatur dalam undang-undang khusus, yakni Undang-Undang Nomor 2 Tahun 2014 tentang Perubahan Atas Undang-Undang Nomor 30 Tahun 2004 tentang Jabatan Notaris (untuk selanjutnya disebut dengan UUJN).

Pejabat umum merupakan seseorang yang mengemban suatu jabatan, yang kemudian diangkat dan diberhentikan oleh negara, yang diberikan kewenangan dan kewajiban untuk dapat memenuhi kepentingan anggota masyarakat di bidang hukum keperdataan. Maka dari itu, notaris merupakan suatu organ negara yang dimana negara memberikan wewenang kepada notaris melalui ketentuan dalam UUJN, untuk mebuat suatu akta yang otentik. Notaris sebagai pejabat umum yang berwenang dalam melaksanakan sebagian tugas kenegaraan, ia tidak hanya bekerja untuk kepentingannya sendiri, melainkan ia juga dituntut untuk dapat bertanggung jawab memenuhi kebutuhan akan pelayanan dan jasa kepada masyarakat terkait dengan perbuatan hukum perdata. ${ }^{3}$ Sehingga, notaris dalam menjalankan tugas dan jabatannya dituntut wajib bersifat mandiri, tidak bergantung kepada siapapun, tidak memihak memandang status sosial atau derajat seseorang dan memiliki kebebasan karena ia berdiri sendiri (unpartiality and Independency). ${ }^{4}$

\footnotetext{
${ }^{1}$ Habib Adjie. (2009). Hukum Notaris Indonesia (Tafsir Tematik Terhadap Undang-Undang Nomor 30 Tahun 2004 tentang Jabatan Notaris). Bandung: PT. Refika Aditama. h. 8.

${ }^{2}$ Arisaputra, M. I. (2012). Kewajiban Notaris Dalam Menjaga Kerahasiaan Akta Dalam Kaitannya dengan Hak Ingkar Notaris. Perspektif, 17(3), 173-183. h. 2.

${ }^{3}$ Rositawati, D., Utama, I. M. A., \& Kasih, D. P. D. (2017). PENYIMPANAN PROTOKOL NOTARIS SECARA ELEKTRONIK DALAM KAITAN CYBER NOTARY. Acta Comitas, 172-182. h. 8 .

${ }^{4}$ Herlien Budiono. (2007). Kumpulan Tulisan Hukum Perdata di Bidang Kenotariatan. Bandung: PT Citra Aditya Bakti. h. 22.
} 
Notaris di berikan kewenangan secara atributif oleh negara, maka dari itu ia wajib melayani masyarakat untuk memenuhi kebutuhan mereka dalam mengatur hubungan-hubungan hukum antara yang satu dengan yang lainnya, yang kemudian dituangkan secara tertulis ke dalam bentuk akta dan dapat digunakan sebagai alat bukti yang berupa dokumen resmi dan memiliki kekuatan pembuktian sempurna. ${ }^{5}$ Dengan adanya kewenangan yang diberikan kepada notaris tersebut, ia harus dapat memberikan jaminan akan kepastian hukum kepada masyarakat yang mebutuhkan jasanya. ${ }^{6}$ Akta otentik yang dibuat oleh notaris pada hakikatnya memuat keterangan sesuai dengan keinginan atau kehendak para pihak yang merupakan suatu kebenaran formal. Apabila notaris telah selesai membuat aktanya, notaris berkewajiban untuk membacakan isi dari akta tersebut di hadapan para penghadap atau klien, yang wajib dihadiri oleh dua orang saksi, dan akta tersebut wajib ditandatangani oleh para pihak atau klien, saksi-saksi dan notaris itu sendiri. ${ }^{7}$ Keberadaan akta notaris dirasa sangat penting bagi masyarakat dalam memenuhi kebutuhan mereka. Oleh karena itu, seorang notaris sudah sepantasnya dapat menjamin adanya kepastian hukum yang dapat diberikan kepada masyarakat terkait pembuatan akta otentik sebagai alat bukti yang memiliki kekuatan pembuktian sempurna. ${ }^{8}$

Pengertian akta otentik lebih lanjut telah ditetapkan dalam Pasal 1868 Kitab UndangUndang Hukum Perdata (untuk selanjutnya disebut dengan KUH Perdata). Berdasarkan ketentuan pasal tersebut, dapat ditarik 3 (tiga) unsur penting yang wajib dipenuhi agar suatu akta dapat dinyatakan sebagai akta otentik, yaitu: ${ }^{9}$

1. Mengenai bentuknya telah ditentukan oleh undang-undang;

2. Mengenai pembuatannya wajib dirumuskan oleh pejabat yang memiliki kewenangan; dan

3. Dibuat di wilayah kewenangan dari pejabat yang membuat akta itu.

Berdasarkan unsur-unsur tersebut di atas, akta otentik termasuk suatu alat bukti tertulis yang berkekuatan sempurna di hadapan pengadilan, apabila terjadi suatu sengketa di kemudian hari. Apabila salah satu unsur dari persyaratan yang telah ditetapkan tersebut tidak dapat terpenuhi, maka hilanglah otentisitas akta tersebut. Dengan kata lain, akta tersebut tidak dapat dinyatakan sebagai alat bukti yang berkekuatan sempurna, melainkan hanya berkekuatan sebagai akta di bawah tangan saja.

Notaris selain mempunyai kewenangan juga mempunyai kewajiban dan larangan yang wajib ia taati dan patuhi. Kewenangan notaris dalam menjalankan tugas dan jabatannya diatur dalam Pasal 15 ayat (1) sampai dengan ayat (3) UUJN. Sedangkan,

\footnotetext{
${ }^{5}$ Punarbawa, P. A., \& Sarjana, I. M. (2018). Kedudukan Hukum Akta Notaris Dalam Pembebanan Hak Tanggungan Atas Nama Warga Negara Asing. Kertha Semaya. h. 20.

${ }^{6}$ H. Salim HS. \& H. Abdullah. (2007). Perancangan Kontrak dan MOU. Jakarta: Sinar Grafika. h. 101-102.

${ }^{7}$ Suwignyo, H. (2009). Keabsahan Cap Jempol sebagai Pengganti Tanda Tangan dalam Pembuatan Akta Otentik. NOTARIUS, 1(1), 63-74.h. 74.

${ }^{8}$ RAHMA, H. F. (2018). TANGGUNG JAWAB DAN AKIBAT HUKUM NOTARIS DALAM MELAKUKAN IDENTIFIKASI DAN VERIFIKASI DATA PENGGUNA JASA DALAM PERMENKUMHAM NOMER 9 TAHUN 2017. h. 51.

${ }^{9}$ Herlien Budiono. Op. Cit. h. 59.
} 
mengenai kewajiban notaris diatur dalam Pasal 16 ayat (1) UUJN. ${ }^{10}$ Kemudian, mengenai larangan notaris diatur dalam Pasal 17 ayat (1) UUJN. Dalam pasal 16 ayat (1) tersebut notaris wajib bertindak secara adil, mandiri, jujur, bertanggung jawab dan bekerja secara profesional dengan tidak memihak dan terpengaruh oleh siapapun. ${ }^{11}$ Dengan adanya peraturan tersebut, notaris dapat lebih dipercaya oleh masyarakat dan kepercayaan itu dapat diperkuat karena masyarakat mengetahui akan adanya suatu kepastian yang terjamin untuk kepentingannya, yang dimana peraturan tersebut juga bertujuan untuk sarana kontrol sosial dalam kehidupan msyarakat. ${ }^{12}$ Sebagai seorang notaris haruslah memperhatikan mengenai perilaku profesi notaris itu sendiri adapun unsur-unsurnya sebagai berikut:

1. Notaris harus memiliki integritas moral yang baik. Pelaksanaan tugas dalam profesi Notaris harus dilandasi pada pertimbangan moral. Meskipun diimingimingi imbalan jasa yang tinggi, tetapi jika hal yang akan dilakukan berbalik arah dengan moral baik yang seharusnya maka hal tersebut patut dihindari.

2. Notaris harus bertindak jujur kepada setiap klien yang datang menghadapnya dan juga kepada diri sendiri (kejujuran intelektual), serta harus mengetahui seberapa kapasitas kemampuannya karena ia tidak boleh memberikan janji-janji yang hanya sekedar untuk menyenangkan hati kliennya agar klien tersebut tetap memerlukan dan memakai jasanya.

Dalam menjalankan tugas dan jabatannya notaris wajib tanggap, peka dan mempunyai ketajaman dalam berfikir, serta dapat memberikan analisis yang baik terhadap fenomena hukum yang ada pada masyarakat. Hal tersebut agar nantinya seorang notaris memiliki keberanian untuk mengambil tindakan dan keputusan yang tepat dalam melakukan pekerjannya sesuai dengan peraturan-perundang-undangan yang berlaku melalui produk yang dibuatnya, yaitu akta otentik. Notaris juga harus memiliki keberanian untuk menolak dengan tegas apabila dalam pembuatan aktanya mengandung unsur yang bertentangan dengan hukum, etika, dan moral. ${ }^{13}$

Jabatan profesi notaris merupakan cerminan kepercayaan masyarakat terhadap hasil pekerjaan berupa akta yang dibuat oleh notaris tersebut. Dari konteks ini jabatan notaris sering pula disebut dengan jabatan kepercayaan. Notaris wajib memberikan pelayanan jasa di bidang hukum perdata kepada masyarakat yang membutuhkannya. Pelayanan diartikan dalam konteks yang luas tidak hanya membuat akta, melakukan legalisasi akta di bawah tangan, memberikan konsultasi atau penyuluhan hukum yang menyangkut bidang kenotariatan, tetapi di samping itu, notaris juga bertugas terkait dengan sejumlah aspek pemberian kemudahan masyarakat mendapatkan informasi tentang persyaratan untuk pembuatan akta otentik serta keramahan notaris beserta

${ }^{10}$ Diana, P. V. P., Mertha, I. K., \& Artha, I. G. (2015). PERTANGGUNG JAWABAN NOTARIS DALAM PEMBUATAN AKTA BERDASARKAN PEMALSUAN SURAT OLEH PARA PIHAK. Acta Comitas, 161-172. h. 6.

${ }^{11}$ Asmara, D. A. (2006). PERANAN NOTARIAT SEBAGAI PEJABAT LELANG DALAM UPAYA SOSIALISASI LELANG DI INDONESIA (Doctoral dissertation, Program Pascasarjana Universitas Diponegoro). h. 76.

12 Prayojana, D. A., Murni, R. R., \& Dharmawan, N. K. S. (2018). PELAKSANAAN PENYELESAIAN PELANGGARAN KODE ETIK NOTARIS TENTANG PEMASANGAN PAPAN NAMA NOTARIS DI KOTA DENPASAR. Acta Comitas, 213-218. h. 2.

${ }^{13}$ Setiawan, W. (2004). Sikap Profesionalisme Notaris Dalam Pembuatan Akta Otentik. Media Notariat, Surabaya. h. 25. 
pegawainya dalam melayani klien. Keseluruhan hal tersebut merupakan bagian dari aktivitas penuh notaris dalam menjalankan profesinya. Berdasarkan pemaparan di atas, penting dilakukannya penelitian mengenai: bagaimanakah efektivitas penerapan etika profesi oleh notaris dalam memberikan pelayanan jasa kepada klien?; dan bagaimanakah akibat hukum terhadap notaris yang tidak melaksanakan etika profesi dalam memberikan pelayanan jasa kepada klien?

\section{Metode Penelitian}

Jenis penelitian ini merupakan penelitian hukum empiris yang meneliti data sekunder di awal penelitian dan dilanjutkan dengan meneliti data primer di lapangan, yaitu responden dari masyarakat secara langsung. ${ }^{14}$ Menurut Soerjono Soekanto, pengertian penelitian empiris adalah penelitian hukum yang terdiri dari penelitian terhadap identifikasi hukum tidak tertulis dan penelitian terhadap efektifitas hukum, terutama bertujuan untuk menelaah perilaku hukum warga masyarakat. ${ }^{15}$ Data primer diperoleh secara langsung oleh peneliti dari sumber pertama. Sedangkan, data sekunder diperoleh dari bahan-bahan kepustakaan, arsip-arsip, dokumen-dokumen yang terdiri dari bahan hukum primer yaitu Kitab Undang-Undang Hukum Perdata (Burgerlijk Wetboek), Undang-Undang Nomor 2 Tahun 2014 tentang Perubahan Atas Undang-Undang Nomor 30 Tahun 2004 tentang Jabatan Notaris, dan Kode Etik Notaris, dan bahan hukum sekunder yaitu buku-buku, karya ilmiah, hasil penelitian terdahulu, hasil karya dari praktisi hukum dan sejenisnya yang terkait dengan penelitian. ${ }^{16}$ Pengumpulan data dalam penelitian ini dilakukan dengan teknik studi kepustakaan tehadap bahan-bahan hukum dan teknik wawancara (interview) secara langsung dengan mengajukan beberapa pertanyaan kepada para informan yang memiliki kewenangan terkait dengan permasalahan yang dibahas untuk mendapatkan jawaban yang relevan. Kemudian setelah dikumpulkan, data-data tersebut dianalisis dengan menggunakan teknik analisis data kualitatif untuk memperoleh kesimpulan yang tepat dan logis. Keseluruhan data primer dan data sekunder yang diperoleh dianalisis dengan disusun secara sistematis, digolongkan dalam pola dan tema, dikategorisasikan dan diklasifikasikan, dihubungkan antara satu data dengan data lainnya, dilakukan interpretasi untuk memahami data dalam situasi sosial, dan dilakukan penafsiran dan perspektif peneliti setelah memahami keseluruhan kualitas data.

\section{Hasil Dan Pembahasan}

\subsection{Penerapan Etika Profesi Oleh Notaris Dalam Memberikan Pelayanan Jasa Kepada Klien}

Notaris merupakan profesi yang menempati jabatan hukum yang bertugas menyediakan pelayanan jasa di bidang hukum perdata kepada masyarakat. Notaris dibebankan dengan tanggung jawab terkait alat bukti otentik yang dibuat oleh notaris tersebut secara tertulis atas berbagai perbuatan hukum. Notaris sebagai penyedia layanan jasa hukum sangat berperan dalam membantu menjamin adanya kepastian dan perlindungan hukum bagi masyarakat dalam konteks pencegahan (preventif). Notaris sebagai pejabat umum, dalam hal tindakan yang dilakukannya bukan bertujuan untuk kepentingan pribadi, tetapi untuk memenuhi kepentingan akan

\footnotetext{
${ }^{14}$ Soerjono Soekanto. (2012). Pengantar Penelitian Hukum. Jakarta: UI Press. h. 52.

${ }^{15}$ Ibid, h. 51.

${ }^{16}$ Ibid.
} 
kebutuhan masyarakat luas yang memerlukan alat bukti otentik. Pekerjaan notaris tidak bisa dipandang sebagai pekerjaan biasa untuk mencari nafkah semata, karena notaris merupakan profesi pengabdian kemanusiaan, di samping harus bekerja secara profesional, tidak memihak, dan independen, ia harus mempunyai sikap, perilaku, dan moral yang baik demi menjaga martabat profesi jabatannya.

Sikap profesionalisme yang harus dimiliki seorang notaris dalam bekerja juga berkaitan dengan keahlian khusus yang ia miliki tentunya di bidang notaris, disertai rasa tangung jawab untuk menjamin terlaksananya kepastian hukum, bekerja dengan menomorduakan kepentingan pribadi, dan bersikap adil tanpa memandang derajat atau stataus sosial seseorang yang akan menjadi kliennya. Notaris dalam melakukan pekerjaannya diharapkan senantiasa memperhatikan etika profesinya sesuai dengan ketentuan yang diatur dalam UUJN dan Kode Etik Notaris, serta peraturan perundang-undangan terkait yang berlaku. Dengan kata lain, seorang notaris dituntut untuk menunjukkan perilaku atau sikap yang etis, dan senantiasa pula mempertahankan harkat dan martabat profesi sesuai dengan hati nurani.

Secara sederhana, etika adalah petunjuk bagaimana sebaiknya manusia bersikap atau bertingkah laku baik dalam kehidupan pribadi maupun kehidupan sosial mereka. Etika tersebut meliputi, petunjuk peraturan tentang keagamaan, kesusilaan, hukum dan adat istiadat setempat. Etika profesi merupakan sikap hidup dalam menjalankan tugas dan jabatannya sebagai pengemban profesi, yakni dalam hal ini profesi notaris. Notaris harus memiliki akhlak yang baik untuk melaksanakan pekerjaannya sesuai dengan etika profesi, karena masyarakat pun tidak dapat mengetahui dan menilai apa saja dan bagaimana saja notaris harus bersikap dalam menjalankan profesinya. Maka dari itu, notaris memerlukan pedoman secara obyektif terhadap sikap dan perilaku yang baik, yang diwujudkan dalam sekumpulan kaidah atau norma yang harus dipatuhi baik secara tertulis maupun tidak tertulis. Pedoman tersebut dapat diartikan sebagai etika dalam arti sempit yaitu, kode etik profesi.

Berdasarkan uraian tersebut, apabila dalam memberikan kepastian hukum bagi klien atau para penghadapnya ia melakukan perbuatan tercela, tentunya akan menjadi sangat berbahaya. Hal tersebut misalnya seperti ikut membantu memanipulasi data dan fakta yang kemudian dituangkan ke dalam akta otentik untuk kepentingan salah satu pihak atau orang-orang tertentu, sehingga dapat merugikan pihak-pihak lainnya yang terkait dalam pembuatan akta tersebut. Oleh karena itu, tidak heran apabila seorang notaris yang sering dipanggil untuk datang ke pengadilan atas suatu kasus tertentu, misalnya ia dapat ditunjuk menjadi seorang saksi untuk menerangkan akta yang telah dibuatnya, atau terlebih lagi apabila ia sempat terlibat menjadi pelaku dalam kasus tersebut, ia pun juga dapat menjadi tersangka. Hal tersebut jelas mengurangi integritas notaris dan kepercayaan akan notaris di mata masyarakat.

Perilaku notaris wajib berlandaskan pada Kode Etik Notaris. Kode Etik Notaris mengatur ketentuan-ketentuan yang harus ditaati dan dipatuhi oleh seorang notaris, baik dalam hal menjalankan jabatannya maupun dalam hal di luar menjalankan jabatannya. Pasal 83 ayat (1) UUJN menentukan sebagai berikut: “Organisasi Notaris menetapkan dan menegakan Kode Etik Notaris". Berdasarkan ketentuan pasal tersebut, Kongres Luar Biasa Ikatan Notaris Indonesia (INI) di Bandung pada tanggal 
27 Januari 2005 menetapkan Kode Etik Notaris yang termuat dalam Pasal 13 Anggaran Dasar Ikatan Notaris Indonesia (INI), yang dirangkum sebagai berikut:

a. Dalam rangka menjaga kehormatan dan keluhuran martabat jabatan notaris, perkumpulan membuat kode etik yang ditetapkan dalam kongres tersebut, yang wajib dijadikan sebagai pedoman yang berisi kaidah-kaidah moral, dan wajib pula ditaati oleh setiap anggota perkumpulan tersebut.

b. Dalam rangka penegakan kode etik, Dewan Kehormatan dapat melakukan upayaupaya untuk meningkatkan integritas para anggota perkumpulan.

c. Pengurus Perkumpulan dan/atau Dewan Kehormatan dapat bekerja sama dan juga saling berkoordinasi dengan Majelis Pengawas dalam melakukan upayaupaya penegakan kode etik.

Menurut Notaris/PPAT I Nyoman Mustika, S.H., M.Hum, “penegakan kode etik dalam hal penerapan etika profesi oleh notaris, yang menjadi acuan utama adalah integritas dan komitmen seorang notaris, demi mempertahankan dan menjaga citra profesi notaris itu sendiri". Penegakan kode etik dapat diartikan sebagai kemampuan perkumpulan notaris dan organisasi notaris untuk menerapkan dan memperkuat prinsip kepatuhan terhadap ketentuan-ketentuan yang menyangkut etika profesi bagi para anggota organisasi notaris tersebut. Kemudian selain itu, penegakan kode etik juga dilakukan untuk memproses adanya dugaan terjadinya suatu pelanggaran etika profesi dan menindaklanjuti anggota notaris yang melanggar ketentuan-ketentuan yang tercantum di dalamnya. Keseluruhan hal tersebut dilakukan untuk menjaga dan mempertahankan kualitas anggota notaris itu sendiri. Mereka harus senantiasa saling memperhatikan dan menjaga kualitas intelektual para anggotanya, agar kualitas pelayanan mereka kepada masyarakat menjadi lebih baik kedepannya.

\subsection{Akibat Hukum Terhadap Notaris Yang Tidak Melaksanakan Etika Profesi Dalam Memberikan Pelayanan Jasa Kepada Klien}

Seorang notaris dalam membuat suatu akta wajib memuat keterangan berdasarkan atas keinginan atau kehendak dari para pihak yang datang menghadap dirinya. Apabila terjadi suatu permasalahan hukum terkait dengan akta yang dibuat oleh notaris di kemudian hari, maka dalam hal ini notaris secara moril wajib untuk bertanggung jawab dan para pihak yang merasa dirugikan juga dapat menuntut pertanggungjawaban kepada notaris tersebut. Mengenai pertanggungjawaban tersebut dapat dimintakan secara perdata atau secara pidana. Dalam hal notaris terbukti melakukan suatu kesalahan terkait dengan akta yang dibuatnya, maka notaris juga dapat dimintakan pertanggungjawaban secara administratif. Untuk dapat memintakan pertanggungjawaban tersebut maka sebelum adanya putusan pengadilan yang tetap, akta notaris tersebut haruslah dianggap sebagai akta yang sah serta mengikat (presumtio justea causa). ${ }^{17}$

Kode Etik Notaris memiliki kekuatan yang mengikat dan mengharuskan bagi notaris dalam memberikan pelayanan jasa kepada kliennya agar berjalan dengan efektif. Menurut Notaris/PPAT I Nyoman Mustika, S.H., M.Hum, "Notaris dalam kewenangannya membuat suatu akta haruslah berpedoman pada ketentuan yang telah diatur dalam UUJN, apabila notaris tersebut terbukti melanggar UUJN, maka ia dapat

\footnotetext{
${ }^{17}$ Hakim, S. H. (2015). Prinsip Kehati-hatian Notaris pada Proses Take Over Pembiayaan Kprs Perbankan Syariah Berdasarkan Prinsip Musyarakah Mutanaqisah (Studi di Bank Muamalat Indonesia). Kumpulan Jurnal Mahasiswa Fakultas Hukum. h. 3.
} 
dituntut secara perdata ataupun pidana, akan tetapi terkait dengan pelanggaran UUJN tersebut dalam hal pembuatan akta otentik, notaris dapat dikenakan sanksi adminstratif yang berupa teguran secara lisan, teguran secara tertulis, sampai dengan pemberhentian secara tidak hormat dari Majelis Pengawas".

Akibat hukum terhadap notaris yang tidak melaksanakan etika profesi dalam memberikan pelayanan jasa kepada kliennya dapat berakibat fatal, baik merugikan pihak notaris maupun kliennya tersebut, serta pihak-pihak terkait lainnya, terutama dalam hal pembuatan akta otentik. Misalnya seperti, notaris dalam membuat akta memuat keterangan palsu yang bertentangan dengan peraturan perundang-undangan yang berlaku, hal tersebut tentu dapat mengakibatkan kerugian yang akan diderita oleh klien atau para pihak yang terkait dalam pembuatan akta tersebut. Pihak yang merasa dirugikan dapat mengajukan gugatan pembatalan akta ke pengadilan. Notaris juga dapat dijatuhi sanksi apabila ia terbukti melanggar UUJN atau Kode Etik Notaris. Sebelum dijatuhkannya sanksi terhadap notaris, tindakan utama yang dapat dilakukan adalah dengan melaporkan notaris tersebut kepada Majelis Pengawas Daerah setempat yang berwenang untuk itu dimana ia berkedudukan. Melalui laporan yang diberikan tersebut, selanjutnya Majelis Pengawas Daerah akan mengambil tindakan untuk memeriksa adanya dugaan terjadinya suatu pelanggaran. Setelah sidang diadakan, Majelis Pengawas Daerah akan merancang dan menyampaikan laporan sebagaimana dimaksud kepada Majelis Pengawas Wilayah sebagaimana berdasarkan Pasal 73 ayat (1) huruf a UUJN.

Kemudian setelah laporan tersebut diterima oleh Majelis Pengawas Wilayah, maka akan diselenggarakan sidang yang bertujuan untuk memeriksa dan memutuskan tindakan atas laporan yang disampaikan oleh masyarakat melalui Majelis Pengawas Daerah tersebut. Berdasarkan Pasal 73 ayat (1) huruf b, Majelis Pengawas Wilayah selanjutnya akan memanggil notaris yang dilaporkan untuk melakukan pemeriksaan atas laporan yang telah diterima. Dan berdasarkan Pasal 73 ayat (1) huruf f, Majelis Pengawas Wilayah kemudian akan memberikan sanksi yaitu berupa teguran secara lisan atau teguran secara tertulis, dan mengusulkan pemberhentian terhadap notaris kepada Majelis Pengawas Pusat yaitu berupa:

a. Pemberhentian sementara selama 3 (tiga) bulan sampai dengan 6 (enam) bulan;

b. Pemberhentian secara tidak hormat.

Setelah laporan terkait pelanggaran notaris dari Majelis Pengawas Daerah ke Majelis Pengawas Wilayah diteruskan kepada Majelis Pengawas Pusat, maka apabila Majelis Pengawas Pusat hendak mengusulkan pemberian sanksi dengan pemberhentian terhadap notaris secara tidak hormat, ia dapat mengajukan kepada Menteri yang berwenang untuk itu. Sanksi pemberhentian secara tidak hormat ini adalah merupakan sanksi terberat yang dijatuhkan terhadap notaris yang melakukan tindakan pelanggaran terhadap UUJN dan Kode Etik Notaris. Hal tersebut sebagagaimana diakui juga oleh Notaris/PPAT I Nyoman Mustika, S.H., M.Hum bahwa, "notaris yang tidak melaksanakan etika profesi dalam memberikan pelayanan jasa kepada kliennya dapat dilaporkan kepada Majelis Pengawas Daerah agar diberikan sanksi sesuai peraturan perundang-undangan yang berlaku ataupun kode etik profesi". 
Kode etik profesi bagi seorang notaris bersifat penting sebagai aturan etis yang harus dipenuhi terkait profesinya, dan juga karena pada hakikatnya pekerjaan notaris lebih condong berorientasi pada kepentingan hukum. Dasar hukum seorang notaris terletak pada aktifitasnya, yakni dalam hal pembuatan akta otentik yang menyangkut status harta benda, hak-hak, dan kewajiban klien atau para pihak yang datang menghadap dirinya dan membutuhkan jasa notaris tersebut. Kode etik profesi berfungsi sebagai kendali, batasan dan aturan untuk menghindari terjadinya tindakan tidak adil sebagai akibat dari perbuatan-perbuatan hukum yang bertentangan dengan norma-norma dan prinsip-prinsip hukum yang berlaku.

\section{Kesimpulan}

Berdasarkan hasil penelitian tersebut, notaris dalam melakukan pelayanan jasa kepada klien atau para pihak yang datang menghadap dirinya, harus bersikap secara etis berdasarkan etika profesinya. Notaris harus bekerja secara profesional, bersikap mandiri, tidak memihak dan bergantung kepada siapa pun, serta independen. Seorang notaris dituntut untuk mampu mempertahankan harkat dan martabat profesi jabatan notaris sesuai dengan hati nurani dalam memberikan pelayanan jasa. Akibat hukum terhadap notaris yang tidak melaksanakan etika profesi dalam memberikan pelayanan jasa kepada kliennya dapat berakibat fatal, baik merugikan pihak notaris maupun kliennya, serta pihak-pihak terkait lainnya, terutama dalam hal pembuatan akta otentik. Pihak yang merasa dirugikan tersebut dapat mengajukan gugatan pembatalan akta ke pengadilan. Notaris juga dapat dijatuhi sanksi apabila ia melanggar UUJN maupun Kode Etik Notaris. Salah satu sanksi tersebut berupa sanksi administratif yaitu teguran secara lisan, teguran secara tertulis, sampai dengan pemberhentian secara tidak hormat dari Majelis Pengawas. Seorang notaris harus memperhatikan etika profesi jabatan yang diembannya terutama dalam memberikan pelayanan jasa kepada klien. Pelayanan jasa yang dilakukan oleh seorang notaris wajib mengacu dan taat pada ketentuan UUJN serta Kode Etik Notaris. Acuan dan ketaatan ini bertujuan agar pelaksanaan profesi notaris dalam mengabdi pada masyarakat tidak menurunkan harkat dan martabat, serta keluhuran profesi notaris. Pelanggaran atas ketentuanketentuan tesebut dapat menyebabkan hilangnya daya otentik suatu akta yang dibuat oleh notaris.

\section{Daftar Pustaka}

$\underline{\text { Buku }}$

Adjie, Habib. (2009). Hukum Notaris Indonesia (Tafsir Tematik Terhadap Undang-Undang Nomor 30 Tahun 2004 tentang Jabatan Notaris). Bandung: PT Refika Aditama.

Budiono, Herlien. (2007). Kumpulan Tulisan Hukum Perdata di Bidang Kenotariatan, Bandung: PT Citra Aditya Bakti.

HS, H. Salim \& H. Abdullah. (2007). Perancangan Kontrak dan MOU. Jakarta: Sinar Grafika.

Soekanto, Soerjono. (2012). Pengantar Penelitian Hukum. Jakarta: UI Press.

\section{Jurnal}

Arisaputra, M. I. (2012). Kewajiban Notaris Dalam Menjaga Kerahasiaan Akta Dalam Kaitannya dengan Hak Ingkar Notaris. Perspektif, 17(3), 173-183.

Diana, P. V. P., Mertha, I. K., \& Artha, I. G. (2015). PERTANGGUNG JAWABAN NOTARIS DALAM PEMBUATAN AKTA BERDASARKAN PEMALSUAN SURAT OLEH PARA PIHAK. Acta Comitas, 161-172. 
Hakim, S. H. (2015). Prinsip Kehati-hatian Notaris pada Proses Take Over Pembiayaan Kprs Perbankan Syariah Berdasarkan Prinsip Musyarakah Mutanaqisah (Studi di Bank Muamalat Indonesia). Kumpulan Jurnal Mahasiswa Fakultas Hukum.

Prayojana, D. A., Murni, R. R., \& Dharmawan, N. K. S. (2018). PELAKSANAAN PENYELESAIAN PELANGGARAN KODE ETIK NOTARIS TENTANG PEMASANGAN PAPAN NAMA NOTARIS DI KOTA DENPASAR. Acta Comitas, 213-218.

Punarbawa, P. A., \& Sarjana, I. M. (2018). Kedudukan Hukum Akta Notaris Dalam Pembebanan Hak Tanggungan Atas Nama Warga Negara Asing. Kertha Semaya.

Rositawati, D., Utama, I. M. A., \& Kasih, D. P. D. (2017). PENYIMPANAN PROTOKOL NOTARIS SECARA ELEKTRONIK DALAM KAITAN CYBER NOTARY. Acta Comitas, 172-182.

Setiawan, W. (2004). Sikap Profesionalisme Notaris Dalam Pembuatan Akta Otentik. Media Notariat, Surabaya.

Suwignyo, H. (2009). Keabsahan Cap Jempol sebagai Pengganti Tanda Tangan dalam Pembuatan Akta Otentik. NOTARIUS, 1(1), 63-74.

\section{Tesis/Disertasi}

Asmara, D. A. (2006). PERANAN NOTARIAT SEBAGAI PEJABAT LELANG DALAM UPAYA SOSIALISASI LELANG DI INDONESIA (Doctoral dissertation, Program Pascasarjana Universitas Diponegoro).

RAHMA, H. F. (2018). TANGGUNG JAWAB DAN AKIBAT HUKUM NOTARIS DALAM MELAKUKAN IDENTIFIKASI DAN VERIFIKASI DATA PENGGUNA JASA DALAM PERMENKUMHAM NOMER 9 TAHUN 2017.

\section{Peraturan Perundang-Undangan}

Kitab Undang-Undang Hukum Perdata (Burgerlijk Wetboek).

Undang-Undang Republik Indonesia Nomor 2 Tahun 2014 tentang Perubahan Atas Undang-Undang Nomor 30 Tahun 2004 Tentang Jabatan Notaris, Lembaran Negara Republik Indonesia Tahun 2014 Nomor 293, Tambahan Lembaran Negara Republik Indonesia Nomor 5602.

Kode Etik Notaris. 